\title{
A Comparative Study between Informal and Formal Finance: A Literature Review
}

\author{
Mai Ahmed Abdelzaher ${ }^{1}$ \\ ${ }^{1}$ Faculty of Commerce,Business Administration Cairo University, Giza, Egypt \\ Correspondence: Mai Ahmed Abdelzaher, Faculty of Commerce,Business Administration Cairo University, Giza, \\ Egypt. E-mail: mai_abdelzaher@foc.cu.edu.eg
}

Received: October 2, 2019

Accepted: November 13, 2019

Online Published: November 14, 2019

doi:10.5430/afr.v8n4p231

URL: https://doi.org/10.5430/afr.v8n4p231

\begin{abstract}
The informal credit system is a prevailing form of economic exchange in emerging countries. It is the predominant form of credit in rural communities because it is based on a culture of reciprocity (Family participation-relativesLoyalty-friends-Neighbour). Informal finance contributes significantly to the growth of small and medium-sized enterprises (SMEs). The present study justifies the wide application of informal finance. We find that these projects suffer from the problem of asymmetrical information. They also offer few guarantees. Informal financiers have an advantage over formal financial organizations, in gathering information on lenders in SMEs. The aim of our study was to explore formal and informal credit systems and to explain the prevalence of informal systems in developing countries. This study concluded that credit from informal sources is superior to credit from formal sources because it results in low rates of default on loans. The study also showed that informal finance and commercial credit have a positive impact on the performance of private companies, measured using the rate of return on assets.
\end{abstract}

Keywords: informal credit, formal credit, asymmetry information

JEL Classifications: G30, G20, G23

\section{Introduction}

The dynamic private sector has contributed rapidly to economic growth, especially in recent years, given that it adds value and trade surplus and is considered the main force in the development of the economy, playing a significant role in advancing the economy and achieving continuous growth. Countries around the world adopt all kinds of financial policies to support the development of companies (Sun and Su, 2011).

Informal and formal funding exist in markets with weak financial institutions and low income levels, and individuals either obtain informal credit or borrow from financial sectors at the same time. Studies have shown that $95 \%$ of borrowers living below the level receive $\$ 2$ a day in Hyderabad, India, and seek to obtain informal sources even with banks. Such funding raises a number of important questions, such as why some borrowers get informal loans despite the existence of official banks, while some individuals get money from both sectors at the same time (Madestam, 2014).

Informal finance can be defined as a contract or agreement being made without resorting to a legal system for the exchange of money at present or in the future, while formal financing can be defined as a formal plan designed to improve individuals' creditworthiness by providing better savings opportunities through many services and loans (Schreiner, 2000).

Informal finance coming from friends and family members may encourage entrepreneurs, due to a mutual insurance between the informal lender and the borrower (Lee and Persson, 2016).

Both formal and informal credits have a range of advantages and disadvantages; the borrower can take advantage of the strengths and avoid weaknesses, enabling him or her to reap the benefits of both. In small businesses, informal credit requires simple information because the nature of its business does not involve a commercial register. Due to the low supply of informal credit and its nonproliferation, the interest rate on informal credit increases the amounts of the loans requested by borrowers, making informal credit less important for large corporations seeking financing for large projects. Often, informal lenders are in a better position to repay loans efficiently, especially if there are strict legal rules that may take a lot of time (Allen and Qian, 2010). 
Through previous studies, we found that the theory of informal finance stems from high repayment risks and the cost of high lending used to test the logic behind informal finance. Consequently, researchers have focused on the change in systematic information and informal finance; the role of informal finance in small and medium enterprises; the impact of informal finance on the performance of companies; the existence of several problems, such as the inability of the formal finance sector to provide services to small enterprises (start-up society); the formal finance sector's need to reduce transaction costs; and varying the level of regular information, the difficulty of identifying it, and the high cost of obtaining it.

The purpose of this article is to discuss formal and informal credit systems and explain the reasons for the prevalence of informal systems. In this paper, I assume there are various informal forms of credit that control credit sources in rural communities, such as personal relationships. I expect that informal credit systems based on forms of social exchange prevail.

Our results indicate that informal finance is not necessarily legal, some informal financial contracts are not legally protected, and informal finance is not regulated by the government. Therefore, there is no interest rate law and there is no need to withhold or maintain liquidity requirements representing a competitive advantage for informal financial firms. It is also clear that informal finance channels have a positive impact on the performance of private companies; the research focuses on the role of formal finance and credit trade in the performance of companies, comparing formal and informal finance in companies.

This study is an attempt to contribute to the practical discussion of informal finance in microfinance, given that these topics have not been resolved thus far. It also aims to identify the variables governing informal finance and its role in supporting small projects. The study also provides a practical framework that enables the organization of informal finance operations and benefits them through the development of microenterprises.

\section{Literature Review}

This section presents some previous studies on the types of lending policies, especially informal finance and formal finance. For each study, the paper addresses the variables covered by the study, the financial market applied to the study, the period covered by the study, and the findings of the study.

Siamwalla et al. (1990) studied the government's lending policies in bank lending in the rural sector, which aimed to increase farmers' incomes. In 1966, it established a state agricultural bank to lend to farmers, and in 1970 it established commercial banks to lend to wide range. The study variables were the percentage of deposits, the volume of loans, the average income, and the size of assets. The researchers applied these variables to the Thailand market, where multiple linear regression was used, from 1975 to 1986 . They concluded that the ratio of dependence on informal finance is higher than the ratio of dependence on official finance.

The same approach was followed by Hoff and Stiglitz (1990), Soyibo (1997), Lin and Sun (2005), Allen et al. (2005), Pham and Lensink (2007), Fridell (2007), Chavis et al. (2009), Pitish and Phlong (2009), Jun and Sun (2011), Degryse and Ongena (2014), Fanta (2015), Steven et al. (2016), and Allen et al. (2019).

Hoff and Stiglitz (1990) studied credit markets in the villages to assess credit policies set by the government, taking into account the problem of the asymmetry of information. The variables of the study were the percentage of official financing for the size of credit, the average interest for each sector, and the volume of transactions for formal and informal finance. The researchers applied the variables to Nigeria, India, and Pakistan, where comparative financial analysis was used from 1951 to 1988 . Hoff and Stiglitz concluded that traditional theory suggests that interest in informal finance is greater than in formal finance.

Soyibo (1997) examined issues related to the origin of informal finance and reconsidered some financial terms. The study variables were loan size, deposit rates, and average monthly interest and were applied to Nigeria and India from 1990 using cluster analysis. Soyibo concluded that credit from informal sources is more advantageous than credit from formal sources.

Pham and Lensink (2007) compared the lending policies of both formal and informal lenders. The study variables were loan maturity date, interest rate, and loan size, and dummy variables were used if the loan was repaid. If the loan was not repaid, the researchers took the number (0) in the period from 1995 to 2000, using measures of dispersion and some measures of central tendency as mediator, applied to Vietnam, Naples, and Uganda. Pham and Lensink concluded that official credit constituted about $38.59 \%$ and informal credit amounted to $\$ 51.61$ thousand. It was also concluded that informal financing in Vietnam is widely applied, but not so in other countries, as shown in table 1 . 
Table 1.

\begin{tabular}{ccc}
\hline Country & Formal finance & Informal finance \\
\hline Uganda & 2.27 & 97.73 \\
Naples & 16.19 & 83.78 \\
Vietnam & 37.00 & 42.28 \\
Peru & 2.80 & 83.90 \\
\hline
\end{tabular}

Source: Pham and Lensink (2007)

Lin and Sun (2005) studied informal finance in small and medium-sized enterprises (SMEs). The variables of the study were loan size, expected profit, total return, and interest rates, applied to developed countries in the period from 1984 to 1998. Lin and Sun concluded that informal finance is popular in SMEs.

Allen et al. (2005) studied the relationship between informal finance and the characteristic of rapid growth. The variables of the study were size, debt, loans, equity, and foreign direct investment in the period from 1999 to 2002, applied to the China market. According to a survey list submitted to 17 companies, informal finance is superior to formal financing.

Fridell (2007) studied the role of formal, informal, and semiformal finance in credit by applying variables to study of economics in the state of Jordan and concluded that informal finance has advantages over formal finance. Fridell asserted that the best way to reach a good credit system is to encourage the development of the informal financial sector.

Chavist, Klapper, and Linessa (2009) addressed the impact of the business environment on the different financing methods of small and new companies. The researchers collected a sample of 70,000 companies and used data from 170 surveys. Most of the companies were small and medium-sized companies, and the variables were applied to 104 developing and developed countries. Chavist et al. (2009) noted that small businesses are less dependent on formal finance, relying heavily on informal finance.

Pitish and Phlong (2009) examined informal credit systems based on the provision and acceptance of loans between individuals on the basis of an oral or written agreement by applying to the commodity market. Pitish and Phlong concluded that informal credit systems are the predominant form of credit in rural communities because they depend on interpersonal relationships, family participation, and cultural exchange.

Jun and Sun (2011) examined the impact of informal finance and commercial credit on the performance of private companies. The study variables were credit size, company size, leverage, and rate of return on assets, applied to China, from 1994 to 2006, with the variables arithmetic mean, standard deviation, minimum and maximum, and Ttest applied. Jun and Sun (2011) submitted a survey list to 19 cities in China where informal finance or commercial credit have had a positive impact on the performance of private companies, measured by ROA, finding that when companies rarely resort to formal finance, tending to rely significantly on self-funds, their financial options are drastically limited because informal finance relieves pressure from the cash flow chain.

Degryse and Ongena (2014) studied formal and informal finance in Chinese companies, collecting data at workplaces. They concluded that informal finance is more beneficial than formal finance.

Fanta (2015) examined the problem of financing SMEs, studying the relationship between SMEs and the acute shortage of official credit by surveying 102 companies selected from 10 industrial sectors in Ethiopia who were involved in obtaining loans and looking for alternative financing mechanisms.

Degryseet.al (2016) studied various types of external financing including formal and informal finance through a random sampling of about 4,300 companies in China and concluded that informal finance is associated with increasing sales growth rate for small companies and low sales growth rate for large companies.

Allen et al. (2019) examined the relationship between informal finance and regular information through a survey of 2,400 companies in 18 cities in China. The comparison between formal and informal financing helps to understand whether a service provider has effective IT technology to overcome ethical risks and what problems hinder formal financing of SMEs. Informal finance, with its advantage of information and oversight mechanisms through social and commercial networks, can bridge the gap between lenders and small businesses, thus increasing a company's growth, whereas the application of formal finance is a major constraint.

Yang (2008) differed from previous studies by using ecology to analyse the economic basis of informal finance and 
to determine its function. The variables in this study were environment and self-financing mechanisms, applied to the Chinese market. Yang concluded that informal finance has a negative impact on formal finance. Ayyagari et al. (2008), Reynolds (2011), Ngalawa and Viegi (2013), and Thai and Turkina (2013) also embraced this thought.

Conversely, Ayyagari et al. (2008) concluded that informal finance is not the main reason behind the rapid growth of the private sector in China; it has been shown that rapid growth is due to an increase in dealings with the formal credit market and, to a lesser extent, with the informal market. The researchers stressed that informal finance is widely used by companies in the private sector.

Reynolds (2011) studied formal and informal finance. The variables of the study were liquidity, average per capita income, profit, and credit size, applied to the US market in 1987, 1993, and 1998. Through the statistical method, with arithmetic mean, minimum, and maximum as variables, Reynolds concluded that formal finance is superior to informal finance.

Ngalawa and Viegi (2013) studied formal and informal finance and their impact on economic activity. The variables of the study were volume of loan, interest rates, and profits, applied to emerging markets to develop a systematic information model in the finance sector. Ngalawa and Viegi concluded that reliance on formal finance is more important than reliance on informal finance.

Thai and Turkina (2013) analyzed formal and informal funding policies in a sample of 52 countries representing 6 continents (Asia, Africa, Europe, Australia, South America, and North America), and descriptive statistics and comparative financial analysis were the bases of comparison. Comparing the rates of formal and informal finance, Thai and Turkina concluded that reducing informal finance and shifting to formal finance were sound courses of action.

The table 2 summarizes the most important results of the studies described above.

Table 2.

\begin{tabular}{cccc}
\hline Researcher & Year & Financial Market & The result \\
\hline Siamwalla.et.al & 1990 & Thailand & Informal finance is better \\
Hoff and Stiglitz & 1990 & Nigeria, India and Pakistan & Informal finance is better \\
Soyibo, A & 1997 & Nigeria, India & Informal finance is better \\
Pham.T and Lensink,R & 2007 & Vietnam, Naples and Uganda & Informal finance is better \\
Lin and Sun & 2005 & developed countries & Informal finance is better \\
Allen.et.al & 2006 & China & Informal finance is better \\
Fridell, M. & 2007 & Jordan & Informal finance is better \\
Chavist.et.al & 2009 & developed countries & Informal finance is better \\
Pisith and Phong,M.A & 2009 & Comedy & Informal finance is better \\
Jun and Sun & 2011 & China & Informal finance is better \\
Degryse and Ongena & 2014 & China & Informal finance is better \\
Fanta,A.B & 2015 & Ethiopia & Informal finance is better \\
Degryse.et.al & 2016 & China & Informal finance is better \\
Allen.et.al & 2019 & China & Informal finance is better \\
Yang & 2008 & China & Formal finance is better \\
Ayyagari.et.al & 2008 & China & Formal finance is better \\
Reynolds, P & 2011 & United States of America & Formal finance is better \\
Thai,M and Turkin,E & 2013 & Asia, Africa, Europe, & Formal finance is better \\
& & Australia, South and North America & \\
Ngalawa,H and Viegi,N & 2013 & Emerging Markets & Formal finance is better \\
\hline
\end{tabular}

Source: Prepared by the researcher 


\section{Discussion}

In the financial literature, researchers use the theory of money lenders, meaning that formal and informal lending are considered alternative policies. The assumptions of informal finance theory can be summarized as follows. First, legal protection of banks is necessary to guarantee the availability of credit, because borrowers may act through bank loans, indicating a moral hazard due to fact that the legal contracts that exist between the parties are weak, leading to limitations of funds on offer.

Second, banks have access to unlimited funds, but informal lenders have resource constraints, according to a survey conducted in financial markets in emerging countries by Conning and Undry (1990). Financial intermediation has not been held, not because there are no local agents but because there is no local intermediary capital. Thus, landlords and borrowers who receive informal credit often get money from banks to finance borrowers' needs as a service.

Third, economies in the least developed countries are often characterized as being unable to compete. In particular, we find that the formal sector banks usually have some market power. Through this framework, it is clear that informal financing affects people's access to credit in two ways. First, informal finance grows banks by allowing long-term formal loans for borrowers. Informal credit improves the relationship between borrowers and banks and increases returns on productivity. Second, informal lenders have the ability to help banks decrease agency costs by allowing them to go through official credit channels through the informal sector. When lending is direct, banks divide a part of the surplus with borrowers to prevent them from switching to another side (Madestam, 2014).

Empirical studies indicated that there are two schools in the thought of informal finance The first school calls that informal finance is major than formal finance(e.g., Siamwalla.et.al (1990) Hoff and Stiglitz (1990), Soyibo,A (1997), Lin and Sun (2005), Allen.et.al (2005), Pham,T and Lensink,R (2007), Fridell, M. (2007), Chavist.et.al (2009) PisithPhlong, M.A (2009), Jun and Sun (2011), Degryse and Ongena (2014), Fanta,A.B (2015), Degryse.al (2016), Allen.et.al(2019). because of:

- Formal lenders do not have the ability to solve the problem of information asymmetry, and so the informal credit sector, characterized by changing interest rates from time to time, appears to solve this problem.

- The formal sector includes effective ways to reduce costs and channel credit through a legal system governing transactions between lenders and borrowers, but under this system, loans are available only in the short term, and thus credit needs are met through the informal credit market.

- The real interest rate in the informal sector is fair, despite the diversity of government credit policies.

- In the absence of the formal sector, the informal sector is able to provide consumer loans during periods of recession.

-The asymmetry theory started from the premise that credit markets are imperfect and function in an environment where information is unavailable. With formal funding, lenders face the problem of information asymmetry, resulting from lenders' inability to predict repayment potential.

- After a bank has granted a loan and before repayment has started, circumstances arise, such as the borrowers' desire to exploit the loan or the different investment environment.

- Informal sources of credit result in low rates of default.

- Institutions may resort to informal funding as a result of restrictions imposed by formal funding.

- Informal lenders have an advantage over formal financial institutions in gathering information on borrowers in SMEs.

- The degree of risk in informal lending is lower than in formal lending.

- Most SMEs do not have sufficient assets for collateral.

- Informal funding bases itself on personal relationships, reputation, and culture.

- Transactions through informal financing are clear and cyclical.

- Informal financing differs from formal financing in that there are no formal contracts and there are specific repayment dates.

- Informal finance has a low cost and its application is always possible, which is considered a disadvantage of formal finance. 
-Informal loans are not interest-free, like those of formal finance.

- Formal borrowing is not in the interest of guaranteed group lending.

- Informal finance allows the borrowing of goods and services without collateral.

- Informal finance has advantages in providing information and control.

- Informal finance achieves increased sales growth for small businesses, while the growth rate is low for large firms.

- Formal finance is very expensive.

The opposing view in the literature argues that formal finance is superior to informal finance, as argued by Yang (2008), Ayyagari et al. (2008), Reynolds (2011), Ngalawa and Viegi (2013), and Thai and Turkina (2013), for the following reasons:

- Informal finance brings exposure to many financial risks.

- Informal funding is not controlled.

- The amount of informal financing amounted to about \$ 102 billion, while the amount of informal financing amounted to about $\$ 145$ billion.

- There is insufficient information on informal funding.

- The financial situation of small enterprises cannot be assessed specifically.

- There is little basis for a relationship between informal finance and productivity.

-The formal and informal finance sectors show that increasing credit in the formal finance sector creates productive capacity, which requires resorting to informal financing to achieve balance.

- The interest rate in the formal and informal finance sectors does not always vary in the same direction. In some cases, interest rates in the two sectors change in opposite directions.

- Formal financing improves companies’ performance.

- Formal financing increases the quality of governance.

- Formal financing creates the right conditions for the progress of the economy.

- Formal financing improves the capacity of individuals in terms of their sources and obligations.

Hoff and Stiglitz (1990) pointed to the traditional theory that the formal and informal sectors coexist, but interest in the formal sector is much less than the informal sector. Interest rates do not balance with the supply and demand of credit, there may be a credit rationing, and lending may not be available at any cost in this case. Rural credit markets do not work like traditional competition markets in terms of the rules that apply. Interest rates may change from lender to lender and can increase by $75 \%$ per year. Sometimes credit is not available at any rate. The policy stems from the existence of high interest rates, which is the supply of cheap credit institutions as an alternative to lenders. It has also been noted that high interest rates reflect the efficiency of the markets, taking into account the risk of default, with the following conclusions, according to Miley:

-The credit markets are divided and interest rates for lenders vary by region and also by repayment potential.

-There are a confined number of commercial lenders in the informal sector despite high interest rates.

-In the informal sector, credit cooperation is linked to transactions in other markets.

-Formal lenders often are present in agricultural areas.

According to Jun and Sun (2011), to find a solution to bridge the credit gap between project financing and bank financing, in the private sector in China, for example, in addition to family investment, bank credit, retained earnings, and internal finance, executives are looking for informal financing channels, which have emerged in the form of informal and commercial credit. Financing through private non-bank financial institutions and commercial credit can be expressed in the form of mutual credit derived from transactions resulting from products such as accounts payable and receivables.

\section{Conclusion}

Informal finance can be defined as a contract or agreement made without recourse to the legal system for the exchange of funds at present or in the future. Formal finance can be defined as a set of formal plans designed to improve the conditions of the poor by providing better savings opportunities through many services and loans. The 
theory of money lending means that formal and informal lending are substitutes for each other. Thus, the article explained why institutions with weak legal standing increase the spread of informal finance in some markets and limit it in other markets, and why formal interest rates can be extremely variable within the same microeconomic system.

In this research, the researcher hypothesized that there are various informal forms of credit that control the sources of credit in rural communities: the existence of interest, mutual exchange between employment and services, collective lending and the provision of formal systems, the provision of informal credit along with guarantees.

Through extrapolation of previous studies, it was found that there are two schools of thought in informal finance. The first school calls for institutions to resort to informal financing due to the restrictions imposed by formal finance on individuals, such as credit policies, interest rates, and credit allocation. The second school attributes formal financing to the existence of informal financing, which lies behind the existence of economic motives. According to this school of thought, informal financial systems must be subject to social responsibility.

It is clear that the credit market has some characteristics such as the coexistence of formal and informal finance. The imperfect information model helps to explain these characteristics. This model assumes incomplete credit markets and operates in an environment where information itself is incomplete. In such markets, borrowers can choose from potential borrowers. Lenders can take measures to ensure payment is fulfilled. In this case, lenders face a range of problems such as information asymmetry and ethical risk.

There is a high probability of additional default, after the disbursement of the loan and before the repayment begins. Some circumstances may arise, such as the desire of borrowers to exploit an opportunity in different ways or a changed investment environment.

In the credit market, there are two types of direct and indirect mechanisms designed to address the problems posed by the imperfect information model.

Lenders summarize indirect mechanisms in the design of contracts, and when borrowers accept these contracts, the lender gets information about the risks expected by the borrowers, causing the lender to take measures to reduce the likelihood of default.

Direct mechanisms depend on lenders' spending resources to screen applicants and execute contracts, resulting in higher interest rates, which may reflect the high cost of these activities.

Many studies have shown that SMEs play a large and important role in developed and developing countries but face a range of difficulties where they have less access to formal finance when compared with large countries. With various informal finance organizations (such as savings and credit management societies or creditors), it was found that informal finance, such as loans from family and friends, is commonly used. Informal finance is also found to be a major source of funding for projects relying more on them than official funding. The question arises as to why informal finance is used by SMEs. The answer to this question is that informal finance is seen as a kind of market interaction that represents policies in the economy, given that formal finance cannot match the demand of small enterprises. Finally, the best way to create a good credit system is to encourage the development of the informal financial sector.

\section{References}

Allen, F., Qian, J., \& Qian, M. (2005). Law finance and economic growth in China. Journal of Finance Economics, 77, 57-116. https://doi.org/10.1016/j.jfineco.2004.06.010

Allen, F., Meijun., Q., \& Jing, X. (2019). Understanding informal financing. Journal of Financial Intermediation, 39, 19-33. https://doi.org/10.1016/j.jfi.2018.06.004

Allen, F. \& Qian, J. 2010. Comparing legal and alternative institutions in finance and commerce. In: Heckman, J., Nelson, R. (Eds.), Global perspectives of rule of law (pp. 118-144). Routledge: New York, NY. https://doi.org/10.2139/ssrn.1136168

Ayyagari, M., Demirgüç-Kunt, M., \& Maksimovic, V. (2008). How important are financing constraints? The role of finance in the business environment. World Bank Economic Review, 2 (3), 483-516. https://doi.org/10.1093/wber/lhn018

Chavist, L. W., Klapper, L. F., \& Inessa, L. (2009). Entrepreneurial finance around the world: The impact of the business environment on financing constraints. Retrieved from https://pdfs.semanticscholar.org/871b/302a7cf997ddac30c7b19913e7c22cd16798.pdf 
Degryse, H., Lu, L., \& Ongena., S, (2014). Informal or formal financing? Or both? First evidence on the co-funding of Chinese firms. KU Leuven - Faculty of Economics and Business Working Paper No. AFI _1380. https://doi.org/10.2139/ssrn.2280391

Degryse, H., Lu, L., \& Ongena., S, (2016). Informal or formal financing? Evidence on the co-funding of Chinese firms. Journal of Finance Intermediation, 27, 31-50. https://doi.org/10.2139/ssrn.2023751

Fanta, A. B. (2015). Informal finance as alternative route to SME access to finance: Evidence from Ethiopia. Journal of Governance and Regulation, 4 (1), 94-102. https://doi.org/10.22495/jgr_v4_i1_c1_p1

Fridell, M. (2007). Exploring the roles of informal, formal and semiformal medium credit in Jordan (Unpublished bachelor's thesis). Lund, Sweden: Lund University School of Economics and Management .

Hoff \& Stiglitz. (2009). Introduction: Imperfect information and rural credit market-puzzle and policy perspective. The World Bank Economic Review, 4 (3), 235-50. http://documents.worldbank.org/curated/en/552841468767072501. https://doi.org/10.1093/wber/4.3.235

Jun \& Sun. (2011). Informal finance trade credit and private firm performance. Nankai Business Review International, 2 (4), 383-401. https://doi.org/10.1108/20408741111178816

Lee, S. \& Persson, P. (2016). Financing from family and friends. Review of Financial Studies, 29(9), 2341-2386. https://doi.org/10.1093/rfs/hhw031

Lin, Y. \& Sun, X. (2005). Information, informal finance and SME financing. Economic Research Journal, 7, 35-44.

Madestam, A. (2014). Informal finance: A theory of moneylenders. Journal of Development and Economic, 107, 157-174. https://doi.org/10.2139/ssrn.1319725

Ngalawa, H. \& Viegi, N. (2013). Interaction of formal and informal financial markets and informal financial markets in quasi-emerging market. Journal of Economic Modelling, 31, 614-624. https://doi.org/10.1016/j.econmod.2013.01.005

Pham, T. \& Lensink, R. (2007). Lending policies of informal, formal and semi-formal lenders evidence from Vietnam. Economics of Transition, 15(2), 181-209. https://doi.org/10.1111/j.1468-0351.2007.00283.x

Pitish, M., \& Phlong., A. (2009). Informal credit system in Combodie. (Thesis).

Reynolds, P. (2011). Informal and early finance support in the business creation process: Exploration with PSEP II data set. Journal of Small Business Management, 49, 27-54. https://doi.org/10.1111/j.1540-627X.2010.00313.X

Schreiner, M. (2000). Informal finance and design of microfinance. Development in Practice, 11(5), 637-640. http://www.microfinance.com

Siamwalla,A., Pinthong,C., Poapongsakorn,N., Satsanguan,P., Nettayarak,P., Mingmaneenakin,. W., \& Tubpun.,Y. (1990). The Thai rural credit system: Public subsidiaries, private information and segmented markets. The World Bank Economic Review, 4(3), 271. http://documents.worldbank.org/curated/en/479661468761101813. https://doi.org/10.1093/wber/4.3.271

Soyibo, A. (1997). The informal finance sector in Nigeria: Characteristics and relationship with the formal sector. Development Policy Review, 15, 5-22. https://doi.org/10.1111/1467-7679.00023

Thai, M. \& Turkina, E. (2013). Marco level determinates of formal entrepreneurship versus informal entrepreneurship. Journal of Business Venturing, 29(4), 490-510. https://doi.org/10.1016/j.jbusvent.2013.07.005

Yang, F. (2008). Research on the informal financial ecology on a Perspective of Financial Ecological Environment, Economist, 5. 